\title{
Untreated and formaldehyde treated protein concentrate mixture in the feeds of bulls
}

\author{
LiIsa Syrjälä and Esko Poutiainen \\ Department of Animal Husbandry, University of Helsinki, 00710 Helsinki 71
}

\begin{abstract}
Twelve bulls within the age period 113-294 days were used in an experiment in which the effect of formaldehyde treatment of protein on the live weight gain and feed utilization was studied. Their rations were a combination of a protein concentrate mixture, barley, mineral and vitamins according to nutrient requirements for a growth rate of $1000 \mathrm{~g} / \mathrm{animal} / \mathrm{day}$. Oats and barley straw was available ad libitum. In the experimental group the protein concentrate mixture was treated with formaldehyde, $0,88 \mathrm{~g} / 100 \mathrm{~g}$ crude protein, whereas in the control group it was untreated. The proportion of treated protein was $45 \%$ of the total protein in the diet. The study involved feeding trials, digestibility and nitrogen balance trials, and rumen fluid investigations.

The live weight gain of the bulls in the experimental group was $10 \%$ better than that of the control group. The amount of feed used per $\mathrm{kg}$ live weight gain was $8 \%$ less in the former group than in the latter. The differences in both cases were, however, not significant $(\mathrm{P}>0,05)$. The differences in the digestibility and nitrogen balance and in the $\mathrm{pH}$, ammonia and VFA concentrations of the rumen fluid between the groups were small and insignificant $(\mathrm{P}>0,05)$.
\end{abstract}

\section{Introduction}

The protection of the dietary protein against ruminal degradation has, during recent years, been the object of many studies in order to improve the utilization of protein by ruminants. The first experiments concerning protected protein were performed with sheep (Chalmers et al. 1954, Ferguson et al. 1967). The results were very promising. The wool growth increased, in some case, even more than $120 \%$. When the effect of protected protein on the live weight gain of sheep and cattle or on milk production was examined, the results were not as positive. In some experiments the protection had an improving effect, but more often it had no effect (WALDo et al. 1973, ScHMidT et al. 1973, Wachira et al. 1974, Clark et al. 1974, SyrJälä et al. 1978 a, $1978 \mathrm{~b})$. The differing results depend to a great degree on the differences in the composition of the ration, especially its protein/energy ratio, in the protein source and the technique and level used in protection. All these factors influence what benefit the protein protection gives. 
The purpose of this experiment was to find out the effect of a protected protein concentrate mixture on the live weight gain and feed utilization of growing bulls. The study involved feeding trials, digestibility and nitrogen balance trials and rumen fluid investigations.

\section{Experimental procedures}

\section{Feeds and feeding}

The experiment was performed with 12 growing bulls which were divided by age, live weight, breed and sex into two comparable groups. The animals' mean age at the experiments beginning was 114 days and their mean weight $139 \mathrm{~kg}$.

The experiment was of 6 months duration including an adaptation period of one week in which the bulls' diet was gradually changed to that of the experimental regime. The experimental diet consisted of oats and barley straw, barley and protein concentrate, plus additional minerals and vitamins. The animals received chopped straw ad libitum. The mixture was prepared from barley and protein concentrate, this fed at a level which satisfied the energy and protein demands of the bulls growing at a rate of $1000 \mathrm{~g} /$ day (DAENICKE and RoHR 1974). Energy and protein obtainable from the straw was negligible. Chemical determinations were made on the feed by standard procedures (PALohermo 1969) and the feeding values obtained from NJF Tables (Anon. 1969, Table 1).

The experimental groups protein concentrate was treated with formaldehyde, used at a rate of $0,88 \mathrm{~g} / 100 \mathrm{~g}$ of protein. The control group was given

Table 1. The mean chemical composition of the feeds.

\begin{tabular}{|c|c|c|c|c|}
\hline & Straw & Barley & $\begin{array}{r}\text { Proteir } \\
\text { untreated }\end{array}$ & $\begin{array}{l}\text { ncentrate } \\
\text { formaldehyde } \\
\text { treated }\end{array}$ \\
\hline $\begin{array}{l}\text { Dry matter, } \% \\
\% \text { of dry matter: }\end{array}$ & 87,7 & 89,1 & 90,5 & 90,3 \\
\hline Ash …........................ & 5,5 & 3,6 & 21,6 & 22,0 \\
\hline Organic matter .......... & 94,5 & 96,4 & 78,4 & 78,0 \\
\hline Crude protein ............ & 3,6 & 12,8 & 41,4 & 41,6 \\
\hline Crude fat ................. & 2,0 & 2,4 & 5,4 & 4,9 \\
\hline Crude fibre..$\ldots \ldots \ldots \ldots$ & 42,3 & 7,2 & 9,0 & 9,0 \\
\hline $\mathrm{N}$-free extract ............. & 46,6 & 74,1 & 22,6 & 22,5 \\
\hline kg/f.u. ........................ & 4,0 & 1,0 & 1,35 & 1,35 \\
\hline DM kg/f.u. .................. & 3,5 & 0,9 & 1,2 & 1,2 \\
\hline $\mathrm{DCP} \%$ in $\mathrm{DM}$ & - & 9,6 & $29,5(x$ & $31,1(x$ \\
\hline DCP g/f.u. & - & 86 & $398(\mathbf{x}$ & $420(x$ \\
\hline
\end{tabular}

x) Values are calculated from digestibility coefficients obtained in this study. f.u. $=$ feed unit

$\mathrm{DM}=$ dry matter

DCP $=$ digestible crude protein 
the same protein concentrate but without formaldehyde treatment. The protein concentrate contained $25 \%$ crushed soya, 21,5\% brewers mash, $15 \%$ meat and bone meal, $8 \%$ molasses, $10 \%$ dried molasses beet pulp, $4 \%$ urea, minerals and vitamins.

Feeding was twice daily at 8.00 and 15.00. Refusals were weighed after morning feeding. The bulls were weighed at the beginning of the experiment, fortnightly during it, and at it's end. Adjustments were made to the quantities of grain and protein concentrate according to these weights every week. 100 g/day of a commercial mineral mixture (Se-Terki) was given.

\section{Physiological experiments}

All animals spent a two week period in the physiological experiment. The first week was an adjustment period. Samples were taken during the second week. There was no alteration to the feeding regime. The physiological experiments consisted of digestibility and nitrogen balance investigations based on total collection methods and of rumen fluid studies. The rumen samples were taken by means of a hose connected to a vacuum pump via the mouth 3 times on the last day of the two week period.

1. In the morning before feeding, at 7.45

2. Two hours after the beginning of feeding, at 10

3. Five hours , , at 13

Determinations of rumen fluid $\mathrm{pH}$ and ammonia were made immediately after sampling, $\mathrm{pH}$ with a Beckman Model 76 meter, and ammonium nitrogen colorimetrically after centrifuging the sample at 2000 r.p.m. for 10 mins (McGullough 1967). The volatile fatty acids (VFA) were determined by the gas chromatographic method (HuIDA 1973).

\section{Results and discussion}

Live weight gain and feed consumption

The mean live weight gain of the bulls in the experimental group was about $10 \%$ better than that of the control group (Table 2, Fig. 1). The feed consumption of the animals was, however, in both groups about the same. The amount of feed used per $\mathrm{kg}$ live weight gain by the bulls of the experimental group was about $8 \%$ less than by the control animals.

The physiological experiments decreased the growth rate in both groups, although the composition and the intake of the diets were the same during this period as during the whole experiment. This reduction of growth rate was, however, compensated for after the physiological study period. The mean live weight gain of the animals before that period, i.e. between 121-189 days of age, was in the experimental group $1015 \mathrm{~g}$ and in the control group $939 \mathrm{~g} /$ day. During the physiological period it was $534 \mathrm{~g}$ and $492 \mathrm{~g} /$ day, respectively. After the physiological period the experiment continued 23 days more and during this time the mean live weight gain in the experimental group was 1756 $\mathrm{g}$ and in the control group $1496 \mathrm{~g} /$ day. 

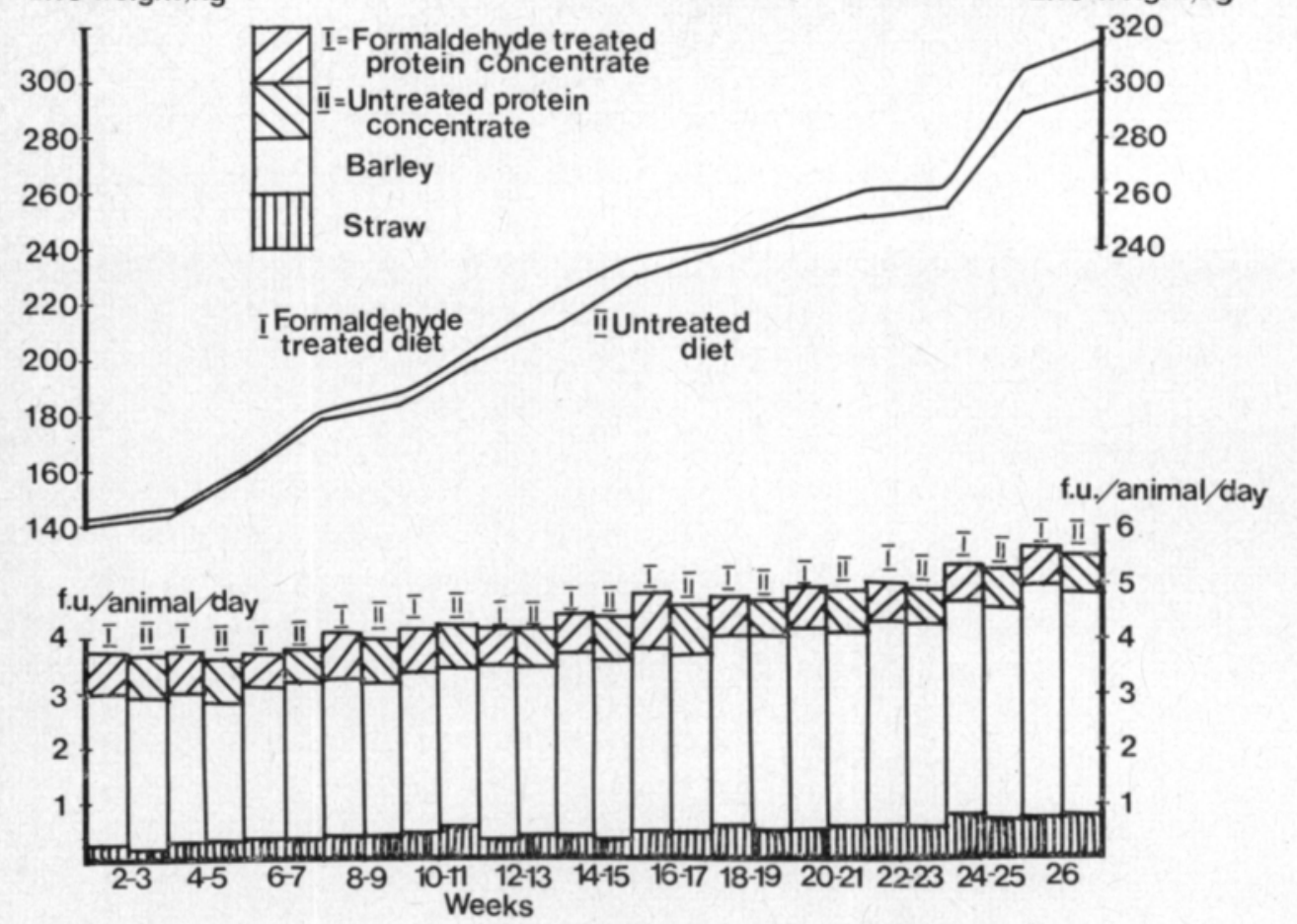

Fig.1. Live-weight gain and feed consumption on different diets

In previous investigations, where formaldehyde protected protein has been used in the diets of growing animals, there have been contradictory results. Formaldehyde treated ground-nut meal in calves diets, containing $12 \%$ protein, increased growth by $9 \%$, while at the higher protein levels, $15 \%$ and $19 \%$, formaldehyde treatment gave no significantly higher growth rates. Formaldehyde was used at a rate of $2 \mathrm{~g} / 100 \mathrm{~g}$ of crude protein (FAICHNEY and DAvies 1973). The calves growth was not different in the control group when compared with that of those on feed containing $26 \%$ formaldehyde treated rape seed meal. Formaldehyde use in this experiment was 5,6 g/100 $\mathrm{g}$ of digestible crude protein (Sharma et al. 1972). Growth and feed consumption were also found to be considerably smaller with beef animals, live weight $350 \mathrm{~kg}$, on formaldehyde treated barley fed ad libitum (DAviEs and FAICHNEY 1973). Negative results were also obtained by SснміDт et al. (1974) with Holstein bulls fed soya beans treated with $40 \%$ - formaldehyde at a rate of 1,5 and $3 \mathrm{ml} / 100 \mathrm{~g}$ of soya protein.

\section{Digestibility and $\mathrm{N}$-balance}

The treatment with formaldehyde lowered the organic matter and crude protein digestibility of the ration but not significantly $(P>0,05$, Table 3$)$. The reason for such a slight decrease was the treatment with only $0,88 \mathrm{~g}$ formaldehyde/100 $\mathrm{g}$ protein concentrate and the fact, that the proportion of this treated protein in the whole diet was only $45 \%$ (Table 2). 
Table 2. Live weight gain and feed consumption.

\begin{tabular}{|c|c|c|}
\hline & $\begin{array}{l}\text { Experimental } \\
\text { group }\end{array}$ & $\begin{array}{c}\text { Control } \\
\text { group }\end{array}$ \\
\hline Number of animals .................. & 6 & 6 \\
\hline 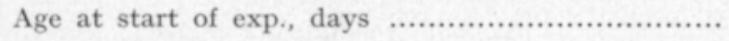 & 112 & 115 \\
\hline Age at end of exp., days ................................... & 293 & 296 \\
\hline 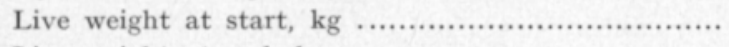 & 140 & 138 \\
\hline 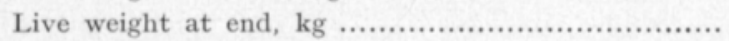 & 313 & 296 \\
\hline 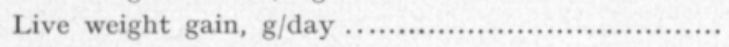 & 956 & 873 \\
\hline 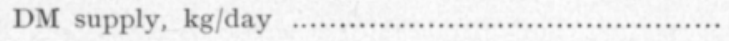 & 5,26 & 5,30 \\
\hline 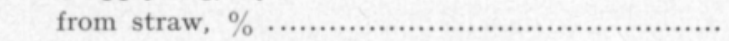 & 32 & 32 \\
\hline from concentrates, $\%$ & 68 & 68 \\
\hline 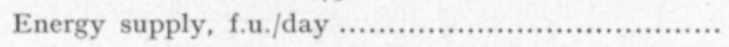 & 4,29 & 4,23 \\
\hline 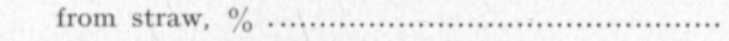 & 11 & 12 \\
\hline 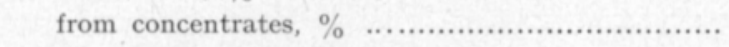 & 89 & 88 \\
\hline \multicolumn{3}{|l|}{ Energy utilization, f.u./kg } \\
\hline live weight gain & 4,48 & 4,85 \\
\hline Crude protein supply, g/day …............................. & 754 & 769 \\
\hline 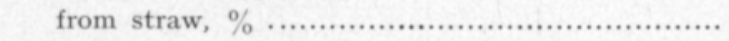 & 8 & 8 \\
\hline 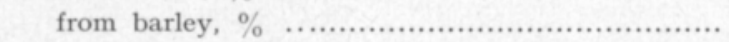 & 47 & 45 \\
\hline from protein conc., $\%$................................... & 45 & 47 \\
\hline 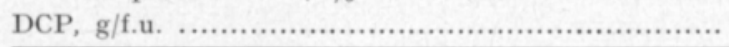 & 140 & 142 \\
\hline
\end{tabular}

Table 3. Digestibility, $\mathrm{N}$ balance and feeding values, calculated for complete diet.

\begin{tabular}{|c|c|c|}
\hline & $\begin{array}{c}\text { Experimental } \\
\text { group }\end{array}$ & $\begin{array}{l}\text { Control } \\
\text { group }\end{array}$ \\
\hline \multicolumn{3}{|l|}{ Digestibility, \% } \\
\hline Organic matter .................. & 69,1 & 69,5 \\
\hline Crude protein ....................... & 62,1 & 63,5 \\
\hline $\mathrm{N}$ balance, g/day ...................... & 16,9 & 15,6 \\
\hline Biological value $. . . \ldots \ldots \ldots \ldots \ldots \ldots \ldots . . . . . . . .$. & 52 & 48 \\
\hline
\end{tabular}

Nitrogen secretion in the urine of the experimental group was lower than that of the control group. This is the main reason why the nitrogen balance was also better in the experimental group. These differences were however not significant $(\mathrm{P}>0.05)$.

In many studies formaldehyde treatment generally lowered feed digestibility, but N-retention has been seen to be same or a little better (REIS and Tunks 1969, Barry 1970, 1972, 1976, Poutiainen and Huida 1970, Faichney 1971, Brown and Valentine 1972, McRae et al. 1972, SyrJäLÄ 1972, Barry and Fennessy 1973). The effect, however, has depended on the level of formaldehyde treatment and also the protein source.

\section{Rumen fermentation}

The mean $\mathrm{pH}$ value of all the rumen fluid samples was 6,94 (Table 4, Fig. 2). This relatively high $\mathrm{pH}$ value has probably been influenced by the neutralising effect of saliva as the rumen samples were taken via the mouth and at least 
some saliva contamination was unavoidable. Although the rumen fluid $\mathrm{pH}$ values were higher in the animals in the experimental group than those of the control group the differences were not significant $(\mathrm{P}>0,05)$. Other studies also confirm that formaldehyde treatment of feeds has no significant effect on the rumen $\mathrm{pH}$ values (Barry 1975, Dinius et al. 1975, Kaufmann and HageMEISTER 1976).

Table 4. $\mathrm{pH}$, ammonia and volatile fatty acids in the rumen fluid of bulls in different groups. The values are the averages of different sampling times.

\begin{tabular}{|c|c|c|}
\hline & $\begin{array}{l}\text { Experimental } \\
\text { group }\end{array}$ & $\begin{array}{l}\text { Control } \\
\text { group }\end{array}$ \\
\hline $\mathrm{pH}$ & 6,94 & 6,94 \\
\hline $\mathrm{NH}_{3}-\mathrm{N}, \mathrm{mg} / 100 \mathrm{ml} \ldots \ldots \ldots \ldots \ldots \ldots \ldots \ldots \ldots \ldots \ldots$ & 11,8 & 11,2 \\
\hline Total VFA, mmoles $/ 100 \mathrm{ml}$....... & 13,65 & 14,22 \\
\hline Acetic acid, molar $\%$.......... & 67,4 & 68,1 \\
\hline Propionic acid,$\quad \ldots \ldots . .$. & 15,8 & 15,4 \\
\hline Butyric acid & 13,9 & 13,6 \\
\hline Isovaleric acid , & 1,7 & 1,5 \\
\hline Valeric acid , & 1,3 & 1,4 \\
\hline Ratio acetic: propionic ............ & 4,3 & 4,4 \\
\hline acetic: butyric .................... & 4,8 & 5,0 \\
\hline " propionic: butyric ........... & 1,1 & 1,1 \\
\hline
\end{tabular}
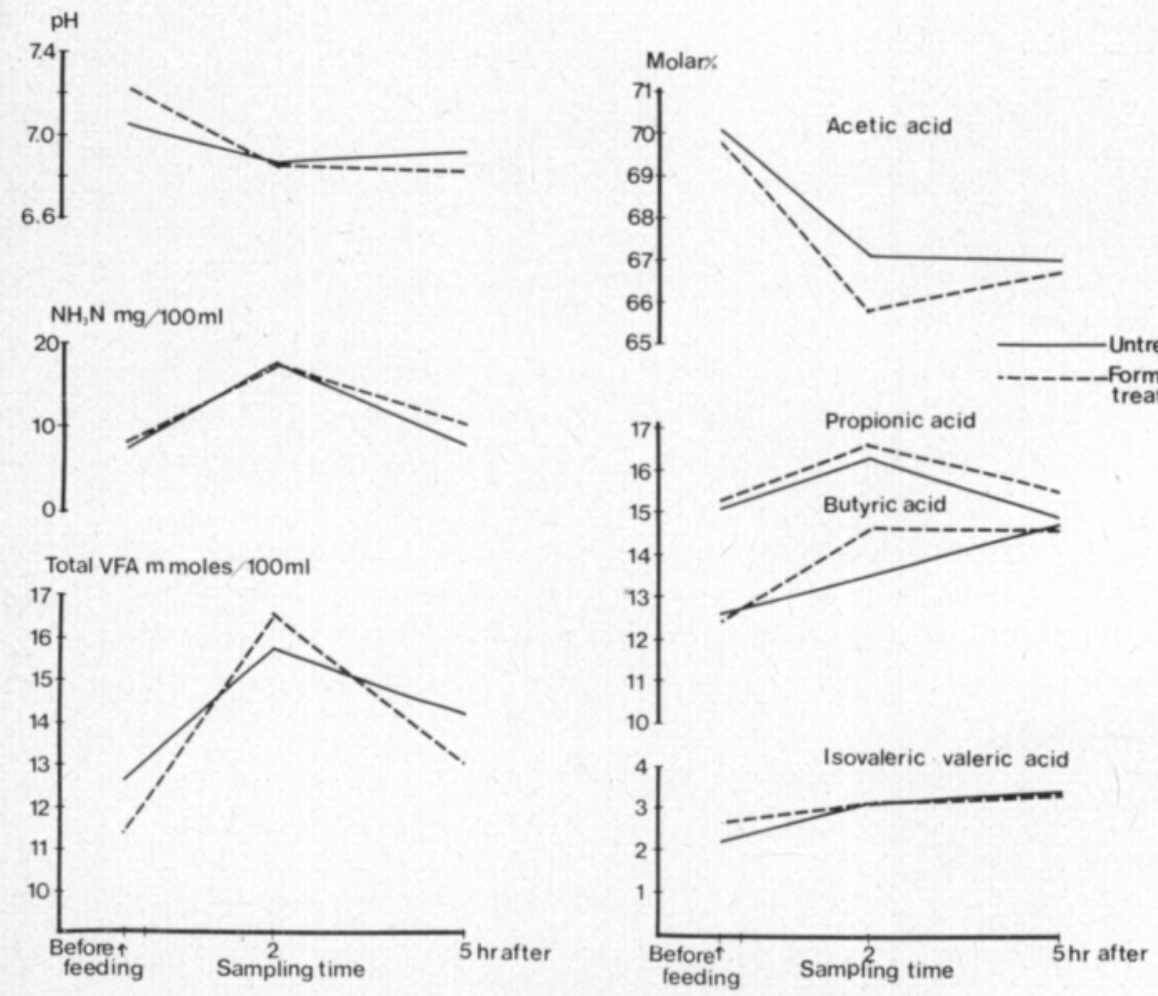

Fig. 2. $\mathrm{pH}, \mathrm{NH}_{3}-\mathrm{N}$ and VFA in the rumen fluid of bulls on different diets 
Treatment with formaldehyde, in this experiment only slightly decreased the ammonia-N level in the rumen fluid. Differences in the values between the groups were not significant $(\mathrm{P}>0,05)$. Generally formaldehyde treatment has been noticed to decrease the ammonia-N levels in the rumen (FAIchney and Davies 1973, Dinius et al. 1975).

The total VFA concentration was lower, but not significantly $(P>0,05)$, in the rumen fluid of bulls in the experimental group than in those in the control group. The lowering effect of formaldehyde treatment on the rumen fluid VFA concentration has also been noticed by BARRY (1975) and DINIUs et al. (1975).

Acknowledgements. - We wish to express our sincere thanks to Mr. Nils Finskas, Mrs. Marjatta Boman and Miss Diane Barnes for helping us to perform this work. We also wish to thank the Farmos Group for prepearing the experimental feeds.

\section{REFERENCES}

Anon. 1969. Fodermiddeltable. Nord. Jorbr. forskenes Foren. 40 p. Gjodvik.

BARRY, T. N. 1970. The effect of formaldehyde treated casein and lucerne meal to sheep on nitrogen metabolism and wool production. Proc. N. Z. Soc. Anim. Production 30: 216-217.

- 1972. The effect of feeding formaldehyde treated casein to sheep on nitrogen retention and wool growth. N.Z.J. Agric. Res. 15:107-116.

- 1975. Evaluation of formaldehyde treated lucerne hay for protecting protein from ruminal degradation and for increasing nitrogen retention, wool growth, live-weight gain and voluntary intake when fed to young sheep. J. Agric. Sci. 85: 2-3.

- 1976. The effectiveness of formaldehyde treatment in protecting dietary protein from rumen microbial degradation. Proc. Nutr. Soc. 35: 221-229.

- \& Fennessy, P. F. 1973. Effect of formaldehyde treatment on the chemical composition and nutritive value of silage. II Digestibility of the silages and the chemical composition of rumen fluid in sheep supplemented or not supplemented with DLmethionine. N.Z. J. Agric. Res. 16:59-63.

Brown, D. C. \& VAlentine, S. C. 1972. Formaldehyde as a silage additive I. The chemical composition and nutritive value of frozen lucerne, lucerne silage and formaldehyde treated lucerne silage. Aust. J. Agric. Res. 23: 1093-1100.

Chalmers, M. I., Cuthbertson, D. P. \& Synge, R. L. M. 1954. Ruminal ammonia formation in relation to the protein requirement of sheep. I. Duodenal administration and heat processing as factors influencing fate of casein supplements. J. Agric. Sci. 44:254262

Clark, J. H., Davies, C. L. \& Hatfield, E. E. 1974. Effect of formaldehyde treated soybean meal on nutrient use, milk yield and composition and free amino acids in the lactating bovine. J. Dairy Sci. 57: 1031-1036.

DAENicker, R. \& RoHR, K. 1974. Rindermast. Land- und Hauswirtschaftlicher Auswertungs und Informationsdienst. Bonn-Bad Godesberg. Nr. 372, 19 p.

Davies, H. L. \& Faichney, G. J. 1973. The effect of formaldehyde treatment of barley on productive performance of Friesian steers. Aust. J. Exp. Agric. and Husb. 13: 142145.

Dinius, D. A., Reynolds, P. J., Lyon, C. K. \& Hohler, G. O. 1975. Digestion and utilization of formaldehyde treated alfalfa meal by sheep. J. Anim. Sci. 40:945-951.

FAichNeY, G. J. 1971. The effect of formaldehyde treated casein on the growth of ruminant lambs. Aust. J. Agr. Res. 22: 453-460. 
Faichney, G. J. \& Davies, H. L. 1973. The performance of calves given concentrate diets treated with formaldehyde. Aust. J. Agric. Res. 24: 613-621.

Ferguson, K. A., Hemsley, J. A. \& Reis, P. J. 1967. Nutrition and wool growth. The effect of protecting protein from microbial degradation in the rumen. Aust. J. Sci. 30: 215217.

Honig, H. \& RoHr, K. 1973. Über den Einfluss von Formalin und formalinhaltigen Zusatzmitteln auf den Silierverlauf und die Vormagenverdauung bei Milchkühen. Wirtschaftseigene Futter 19: $21-30$.

HUIDA, L. 1973. Quantitative determination of volatile fatty acids from rumen sample and silage by gas-liquid chromatography. J. Scient. Agr. Soc. Finl. 45: 483-488.

Kaufmans, W. \& Hagemeister, H. 1976. Zum Einfluss den Behandlung von Protein mit Formaldehyd auf die bakteriell Proteinsynthese und die Abbaurate von Protein in den Vormagen von Milchkühen sowie auf die Verdaulichkeit des Proteins im Darm. Kieler Milchwirtsch. Forsch. Berichte 28: 335-346.

MacRae, J. C., Ulyatt, M. J., Pearce, P. D. \& Hendtlass, J. 1972. Quantitative intestinal digestion of nitrogen in sheep given formaldehyde treated and untreated casein supplements. Brit. J. Nutr. 27: 39-50.

McGullovgh, H. 1967. The determination of ammonia in whole blood by a direct colorimetric method. Clin. Chim. Acta. 17: 297-304.

PALонermo, L. 1969. Weender Analyse. Hanb. der Tierernährung 164-171, Hamburg und Berlin.

Poutrainen, E. \& HUIDA, L. 1970. Eri säilöntäaineilla valmistettujen nurmisäilörehujen laatu ja sulavuus. Koetoim. ja käyt. 27: 7-8.

REIs, P. J. \& Tunks, D. A. 1969. Evaluation of formaldehyde treated casein for wool growth and nitrogen retention. Aust. J. Agric. Res. 20: 775-781.

Schmidt, S. P., Jørgensen, N. A., Benevenga, N. J. \& Brungardt, V. H. 1973. Comparison of soybean meal, formaldehyde treated soybean meal, urea and starea for steers. J. Anim. Sci. 37: 1233-1237.

- , Benevenga, N. J., Jorgensen, N. A. 1974. Effect of formaldehyde treatment of soybean meal on the performance of growing steers and lambs. J. Anim. Sci. 38: 646653.

Sharma, H. R., Ingalls, J. R. \& McKirdy, J. A. 1972. Nutritive value of formaldehydetreated rapeseed meal for dairy calves. Can. J. Anim. Sci. 52: 363-371.

SyrJäLÄ, L. 1972. Effect of different sucrose, starch and cellulose supplements on the utilization of grass silages by ruminants. Ann. Agric. Fenn. 11: 199-276.

- , Poutiainen, E. \& Koskela, V. H. 1978 a. Untreated and formaldehyde treated skimmilk powder as a protein supplement of dairy cows. J. Scient. Agric. Soc. Finl. 50: $155-165$.

- , Syväoja, E.-L. \& Boman, M. 1978 b. Utilization of untreated and formaldehyde treated skimmilk powder and skimmilk powder-barley pellets by ruminants. J. Scient. Agric. Soc. Finl. 50: 166-176.

Wachira, J. D., Satter, L. D., Brooke, G. P. \& Pope, A. L. 1974. Evaluation of formaldehyde treated protein for growing lambs and lactating cows. J. Anim. Sci. 39: 796807.

Waldo, D. R., Keys, J. E. Jr. \& Gordon, C. H. 1973. Formaldehyde and formic acid as a silage additive. J. Dairy Sci. 56: 229-232.

Ms received January 31, 1979. 


\section{Käsittelemätön ja formaldehydillä käsitelty valkuaistiiviste lihanaudan rehussa}

\section{LiISA SyrJÄLÄ ja Esko Poutiainen}

Helsingin yliopiston kotieläintieteen laitos, 00710 Helsinki 71

Tutkimuksen tarkoituksena oli selvittää formaldehydillä tapahtuvan rehuvalkuaisen suojauksen vaikutusta lihanaudan kasvuun ja rehun hyväksikäyttöön. Koe suoritettiin 12 mullilla ikävälillä $113-294$ vrk. Väkirehuseos valmistettiin valkuaistiivisteestä, ohrasta sekä kivennäisistä ja vitamiineista, joiden keskinäinen suhde ja annostustaso muutettiin viikottain ravinnontarvetta vastaavaksi, kun kasvutavoite oli $1000 \mathrm{~g} / \mathrm{el} / \mathrm{pv}$. Kauran ja ohran olkea eläimet saivat vapaasti. Koeryhmän valkuaistiiviste oli käsitelty formaldehydillä, $0,88 \mathrm{~g} / 100 \mathrm{~g}$ raakavalkuaista. Kontrolliryhmän tiiviste oli käsittelemätöntä. Formaldehydillä käsitellyn valkuaisen osuus oli vain $45 \%$ koko rehuannoksen valkuaisesta. Ruokintakokeen lisäksi tutkimukseen kuului sulavuus- ja typpitasekokeet sekä pötsinestetutkimuksia.

Koeryhmän eläinten kasvu oli noin $10 \%$ parempi kuin kontrolliryhman eläinten kasvu. Rehunkäyttö kasvukiloa kohti oli edellisessä ryhmässä noin $8 \%$ vähäisempää kuin jälkimmäisessä ryhmässä. Mainitut erot eivät kuitenkaan olleet tilastollisesti merkitseviä. Myöskään rehun eri aineosien sulavuudessa ja typpitaseessa sekä pötsinesteen $\mathrm{pH}$ :ssa, ammoniakin ja haihtuvien rasvahappojen määrissä ei ollut merkitseviä eroja ryhmien vălillä. 